\title{
Scanner Patient Bed Position
}

National Cancer Institute

\section{Source}

National Cancer Institute. Scanner Patient Bed Position. NCI Thesaurus. Code C94978.

A designated location of the bed as it is moved through the scanner for purposes of positioning a desired part of the subject in the field of view. 